\title{
Early nutrition, epigenetics and cardiovascular disease
}

\author{
Elena Loche ${ }^{1}$ and Susan E. Ozanne ${ }^{1 *}$ \\ ${ }^{1}$ University of Cambridge Metabolic Research Laboratories and MRC Metabolic Diseases Unit, \\ Addenbrooke's Hospital, Cambridge, CB2 0QQ, UK \\ *Corresponding author: Prof Susan Ozanne \\ University of Cambridge Metabolic Research Laboratories and MRC Metabolic Diseases Unit \\ Wellcome Trust-MRC Institute of Metabolic Science, Level 4, Box 289, \\ Addenbrooke's Treatment Centre, Addenbrooke's Hospital, Cambridge, CB2 OQQ, United Kingdom \\ E-mail address: seo10@cam.ac.uk \\ Telephone: $+44(0) 1223762636$
}

\section{Purpose of review:}

Here, we provide a summary of the current knowledge on the impact of early life nutrition on cardiovascular diseases that have emerged from studies in humans and experimental animal models. The involvement of epigenetic mechanisms in the Developmental Origins of Health and Disease $(\mathrm{DOHaD})$ will be discussed in relation to the implications for the heart and the cardiovascular system.

\section{Recent findings:}

Environmental cues, such as parental diet and a suboptimal in utero environment can shape growth and development, causing long-lasting cardiometabolic perturbations. Increasing evidence suggest that these effects are mediated at the epigenomic level, and can be passed onto future generations. In the last decade, epigenetic mechanisms (DNA methylation, histone modifications) and RNA-based mechanisms (microRNAs [miRNAs], Piwi-interacting RNA [piRNAs] and transfer RNA [tRNA] fragments) have therefore emerged as potential candidates for mediating inheritance of cardiometabolic diseases.

\section{Summary:}

The burden of obesity and associated cardiometabolic diseases is believed to arise through interaction between an individual's genetics and the environment. Moreover, the risk of developing poor cardiometabolic health in adulthood is defined by early life exposure to pathological cues and can be inherited by future generations, initiating a vicious cycle of transmission of disease. Elucidating the molecular triggers of such process will help tackle and prevent the uncontrolled rise in obesity and cardiometabolic disease.

\section{Keywords:}

Maternal diet, cardiovascular diseases, heart, epigenetics, early nutrition, fetus, obesity, metabolism 


\section{KEY POINTS}

- The Developmental Origins of Health and Disease (DOHaD) hypothesis suggests that the environment experienced in early in life can influence the long-term cardiovascular health of an individual;

- Studies in humans and animal models suggest that a suboptimal environment during early life increases the risk of cardiovascular disease in the offspring;

- The epigenome is sensitive to dietary challenges applied during critical windows of development (fetal and early post-natal);

- Recently, small non-coding RNAs have been proposed as mediators of intergenerational programming of metabolic diseases through the paternal line;

- The contribution of epigenetic mechanisms to the programming of cardiovascular diseases by early life disturbances is relatively unexplored.

\section{INTRODUCTION}

The Developmental Origins of Health and Disease (DOHaD) hypothesis proposes that exposure to detrimental stimuli during pre-natal and early post-natal life can shape the long-term health of an individual. The developing fetus is extremely sensitive to the external environment, and adapts its physiology in order to increase its survival post-natally. This idea was first conceptualised as the Thrifty Phenotype Hypothesis in the early 90's by David Barker and colleagues who suggested that the fetal environment is a major determinant of long-term cardiometabolic health [1]. Although initial studies focussed on the detrimental effects of fetal under-nutrition, subsequent studies in humans and animal models have consistently reported that either deficiency (undernutrition) or excess (overnutrition) availability of nutrients, oxygen and hormones influence tissue development, and lead to an increased risk of "non-communicable diseases" in the adult progeny including obesity, type-2 diabetes (T2D) and cardiovascular diseases (CVD) [2]. In this context, nutritional imbalances applied during "critical windows" of development (fetal and post-natal life) can induce permanent changes to the structure and function of organs and systems, predisposing the fetus to an increased risk of diseases later in life.

\section{CARDIOVASCULAR DISEASE RISK: THE IMPACT OF FETAL LIFE}

The balance of nutrient supply during gestation and lactation is critical to ensure correct fetal development and growth. Failure of the fetus to meet the nutritional demand may result in in utero growth restriction (IUGR) and high risk of delivering a low birth weight (LBW) baby, both of which have been associated with increased risk of cardiovascular diseases [3]. Birth weight is a proxy of fetal health and predicts the risk of T2D in a U-shaped manner, with babies at both ends of the curve being more at risk [4]. LBW is an independent risk factor for cardiovascular diseases (CVD) in adulthood, 
inversely correlates with systolic blood pressure (SBP) [5, 6], and associates with increase mortality from coronary heart disease [7] and higher risk of hypertension [8]. IUGR in human pregnancies has been strongly linked to poor cardiovascular health already in utero, such as altered parameters of systolic and diastolic function [9, 10], and throughout infancy and adulthood [11]. Consistently, studies conducted on various experimental models of fetal growth restriction (nutritional, hypoxia, glucocorticoid exposure, diabetes) have identified the cardiovascular system as a major target of developmental programming, and have shown that control of cardiomyocyte number and size may play an important role in this process [12]. IUGR babies have a higher risk of being born Small for Gestational Age (SGA), and often undergo a rapid (catch-up) growth early after birth in an attempt to compensate for the slow uterine development. This causes long-lasting changes to the structure and metabolism of an organism.

\section{EARLY POST-NATAL LIFE: NUTRITION AND GROWTH}

As well as during fetal life, suboptimal nutrient availability early after birth can impair offspring growth and also program a higher risk of metabolic diseases. In humans, overfeeding and excess post-natal weight gain is causally linked to offspring insulin resistance, obesity and CVD [13-15]. Similarly, a restricted period of overfeeding during lactation results in an increased incidence of obesity in adult baboons [16, 17] and only partially in rodents [18]. More recently, it has been shown in humans that accelerated neonatal growth was associated with the expression of obesity genes [19], confirming once more the strong causal relationship between altered growth trajectory and risk of obesity.

Common ways of promoting post-natal growth in animals are manipulation of litter size or crossfostering. Litter size reduction induces post-natal overfeeding in rodents, via reducing pup competition for maternal milk and consequently increasing pup energy intake. The cardiovascular system is particularly sensitive to nutritional imbalances during lactation [18]. Studies on overfed pups in rodents have shown that overnutrition during lactation results in left ventricular cardiac hypertrophy and increased susceptibility to ischemia-reperfusion injury [20], impaired insulin signalling [21]* and leptin signalling [22], and leads to dysregulation of gene expression of cardiac structural proteins [23].

Cross-fostering is a husbandry practice where new born pups are assigned to a surrogate control mum in order to promote catch-up growth and development in IUGR pups. Increased cardiac DNA damage and oxidative stress was reported in hearts of IUGR rats born to under-nourished mothers which underwent a rapid catch-up growth post-natally [24, 25], as well as increased risk of T2D [26] and reduced longevity [27] .

\section{THE MATERNAL ENVIRONMENT AND CARDIOVASCULAR DISEASE IN ADULTHOOD}

The causal link between suboptimal exposures during fetal life and poor cardiovascular outcomes in later life has been extensively highlighted in human epidemiological studies. Studies on the Dutch Famine Birth Cohort revealed that individuals who were in utero during the famine in the Netherlands, 
when compared with those not exposed had a lower birth weight and had a higher prevalence of coronary heart disease $[28,29]$. Poor cardiovascular outcomes are also common in babies born to type1 diabetic mothers, and this is thought to be a consequence of the teratogenic effects of maternal hyperglycaemia. Among those, congenital heart defects [30], increased cardiac ventricular output [31], reduced cardiac function, cardiac hypertrophy [32] and increased heart rate [33] are observed in babies born to diabetic mothers. Similarly, maternal hypoxia increases the risk of delivering a growth-restricted baby [34], which will develop high blood pressure and chronic hypertension in the long-term, exposing the offspring to a high risk of heart failure [35]. Similar observations have been reported in offspring born to obese mothers. A positive association between maternal Body Mass Index (BMI) and increased offspring risk of hospital admission and premature death for cardiovascular events has been revealed by the Aberdeen Cohort study [36]; in addition, findings from the Helsinki Birth Cohort Study indicated that higher maternal BMI was associated with an increased risk of CVD and T2D diabetes among the offspring [37]. Excessive gestational weight gain leads to pregnancy complications, such as gestational diabetes and pre-eclampsia, which expose the offspring to increased risk of cardiometabolic diseases [38]. Fetuses from obese mothers were shown to be insulin resistant in utero [39], and to develop fetal myocardial dysfunction [40, 41*]. Most importantly, such cardiometabolic perturbations were significantly ameliorated in human offspring born to obese mothers after gastrointestinal bypass compared to age matched siblings born before the surgery [42]. Maternal bariatric surgery resulted in a significant improvement in the metabolic and cardiovascular profile of offspring born after the surgery, reflected by ameliorated insulin sensitivity and reduced systolic blood pressure [43]**.

In parallel, evidence from animal models of dietary manipulation including undernutrition (caloric restriction, low protein diet) and overnutrition (high-fat diet, obesogenic diet) have reinforced the causative link between suboptimal maternal environment and CVD risk in adulthood, and have been important in the characterization of the complex mechanisms underlying the developmental programming of CVD (table 1).

\begin{tabular}{|c|c|c|c|c|c|}
\hline $\begin{array}{c}\text { Maternal } \\
\text { diet }\end{array}$ & Species & $\begin{array}{l}\text { Timing of } \\
\text { exposure }\end{array}$ & Cardiovascular outcome & $\begin{array}{c}\text { Sex } \\
\text { studied }\end{array}$ & Reference \\
\hline \multirow[t]{3}{*}{ High-fat } & mouse & $\begin{array}{l}\text { in utero } \\
\text { and } \\
\text { lactation }\end{array}$ & Hypertension & $\mathrm{M}$ and $\mathrm{F}$ & [44] \\
\hline & mouse & $\begin{array}{l}\text { in utero } \\
\text { and } \\
\text { lactation }\end{array}$ & $\begin{array}{l}\text { Hyperglycaemia, insulin } \\
\text { resistance, obesity, and } \\
\text { hypertension }\end{array}$ & $\mathrm{F}$ & [45] \\
\hline & rat & $\begin{array}{l}\text { in utero } \\
\text { and } \\
\text { lactation }\end{array}$ & $\begin{array}{l}\text { Increased lipid peroxidation } \\
\text { and evidence of mitochondrial } \\
\text { dysfunction }\end{array}$ & $\begin{array}{c}\text { not } \\
\text { available }\end{array}$ & [46] \\
\hline
\end{tabular}




\begin{tabular}{|c|c|c|c|c|c|}
\hline & rat & $\begin{array}{l}\text { in utero } \\
\text { and } \\
\text { lactation }\end{array}$ & Vascular dysfunction & $\begin{array}{c}\text { not } \\
\text { available }\end{array}$ & {$[47]$} \\
\hline & rat & $\begin{array}{l}\text { in utero } \\
\quad \text { and } \\
\text { lactation }\end{array}$ & $\begin{array}{c}\text { High systolic and diastolic } \\
\text { blood pressure, abnormal } \\
\text { vascular function, reduced } \\
\text { endothelium-dependent } \\
\text { relaxation } \\
\end{array}$ & $\mathrm{M}$ and $\mathrm{F}$ & $\begin{array}{c}{[48],[49],} \\
{[50],[51,} \\
52]\end{array}$ \\
\hline & rat & in utero & $\begin{array}{c}\text { Cardiac vulnerability to } \\
\text { ischemic injury in adult male } \\
\text { offspring }\end{array}$ & $\mathrm{M}$ and $\mathrm{F}$ & {$[53]^{*}$} \\
\hline & rat & $\begin{array}{l}\text { in utero } \\
\text { and } \\
\text { lactation }\end{array}$ & $\begin{array}{c}\text { Increased blood pressure, } \\
\text { insulin resistance, } \\
\text { dyslipidaemia, obesity and } \\
\text { mesenteric artery endothelial } \\
\text { dysfunction in adult offspring }\end{array}$ & $\mathrm{M}$ and $\mathrm{F}$ & [54] \\
\hline & sheep & in utero & $\begin{array}{c}\text { Fibrosis and collagen } \\
\text { deposition }\end{array}$ & $\mathrm{M}$ and $\mathrm{F}$ & {$[55]$} \\
\hline & sheep & in utero & $\begin{array}{c}\text { Impaired cardiac insulin } \\
\text { signalling and impaired left- } \\
\text { ventricular-developed pressure } \\
\text { in response to high workload } \\
\text { stress. }\end{array}$ & $\mathrm{M}$ and $\mathrm{F}$ & {$[56]$} \\
\hline & sheep & in utero & $\begin{array}{l}\text { Myofibril hypertrophy and } \\
\text { fascicular disarray }\end{array}$ & $\mathrm{M}$ and $\mathrm{F}$ & {$[57]$} \\
\hline & $\begin{array}{l}\text { Japanese } \\
\text { macaque }\end{array}$ & $\begin{array}{l}\text { in utero } \\
\text { and } \\
\text { lactation }\end{array}$ & $\begin{array}{c}\text { Vascular dysfunction } \\
\text { manifested as depressed } \\
\text { endothelium-dependent } \\
\text { vasodilatation and thickened } \\
\text { intima wall }\end{array}$ & $\begin{array}{c}\text { not } \\
\text { available }\end{array}$ & [58] \\
\hline $\begin{array}{c}\text { High } \\
\text { fat/high } \\
\text { sugar } \\
\text { (obesogenic) }\end{array}$ & mouse & $\begin{array}{l}\text { in utero } \\
\text { and } \\
\text { lactation }\end{array}$ & $\begin{array}{l}\text { Hypertension, cardiac } \\
\text { hypertrophy and cardiac } \\
\text { dysfunction ex vivo }\end{array}$ & M & $\begin{array}{c}{\left[59^{*}, 60\right]} \\
{[61,62]}\end{array}$ \\
\hline \multirow[t]{6}{*}{$\begin{array}{l}\text { Caloric } \\
\text { restriction }\end{array}$} & mouse & $\begin{array}{l}\text { in utero } \\
\text { and } \\
\text { lactation }\end{array}$ & $\begin{array}{l}\text { Increase in systolic blood } \\
\text { pressure, perivascular fibrosis } \\
\text { of the coronary artery, } \\
\text { cardiomegaly and } \\
\text { cardiomyocyte hypertrophy }\end{array}$ & M & {$[63,64]$} \\
\hline & rat & $\begin{array}{l}\text { in utero } \\
\text { and } \\
\text { lactation }\end{array}$ & Endothelial dysfunction & M & {$[65]$} \\
\hline & rat & in utero & Elevated blood pressure & $\mathrm{M}$ and $\mathrm{F}$ & {$[66]$} \\
\hline & rat & $\begin{array}{l}\text { in utero } \\
\text { and } \\
\text { lactation }\end{array}$ & $\begin{array}{l}\text { Persistent hypertension and } \\
\text { endothelial dysfunction across } \\
\text { F1-F3 offspring }\end{array}$ & M & [67] \\
\hline & rat & in utero & $\begin{array}{l}\text { Reduced heart weight and } \\
\text { cardiomyocytes number at } \\
\text { birth }\end{array}$ & $\mathrm{F}$ & [68] \\
\hline & rat & in utero & $\begin{array}{c}\text { Pathological cardiac } \\
\text { remodeling, diastolic } \\
\text { dysfunction, altered } \mathrm{Ca}^{2+}\end{array}$ & $\mathrm{M}$ and $\mathrm{F}$ & {$\left[69^{*}, 70\right]$} \\
\hline
\end{tabular}




\begin{tabular}{|c|c|c|c|c|c|}
\hline & & & $\begin{array}{l}\text { handling properties is isolated } \\
\text { cardiomyocytes }\end{array}$ & & \\
\hline & rat & in utero & $\begin{array}{l}\text { Hypertension and reduced } \\
\text { number of glomeruli }\end{array}$ & M & [71] \\
\hline & sheep & $\begin{array}{l}\text { Gestation } \\
\text { and/or } \\
\text { lactation }\end{array}$ & $\begin{array}{l}\text { Hypertension and impaired } \\
\text { glomerulogenesis }\end{array}$ & M & [72] \\
\hline & sheep & in utero & $\begin{array}{l}\text { Left and right ventricular } \\
\text { cardiac hypertrophy (fetus and } \\
\text { adult offspring) }\end{array}$ & $\mathrm{F}$ & {$[73,74]$} \\
\hline \multirow[t]{10}{*}{ Low protein } & mouse & $\begin{array}{l}\text { in utero } \\
\text { and } \\
\text { lactation }\end{array}$ & $\begin{array}{l}\text { Elevated offspring systolic } \\
\text { blood pressure }\end{array}$ & $\mathrm{M}$ and $\mathrm{F}$ & [75] \\
\hline & mouse & $\begin{array}{l}\text { in utero } \\
\text { and } \\
\text { lactation }\end{array}$ & Cardiac hypertrophy & M & [76] \\
\hline & mouse & $\begin{array}{l}\text { in utero } \\
\text { and } \\
\text { lactation }\end{array}$ & $\begin{array}{c}\text { Hypertension and vascular } \\
\text { dysfunction }\end{array}$ & $\mathrm{M}$ & [77] \\
\hline & rat & $\begin{array}{l}\text { in utero } \\
\text { and } \\
\text { lactation }\end{array}$ & $\begin{array}{l}\text { Reduced cardiac beta- } \\
\text { adrenergic responsiveness }\end{array}$ & $\mathrm{M}$ & [78] \\
\hline & rat & $\begin{array}{l}\text { in utero } \\
\text { and } \\
\text { lactation }\end{array}$ & $\begin{array}{l}\text { Increase in the cardiovascular } \\
\text { sympathetic tone }\end{array}$ & M & [79] \\
\hline & rat & in utero & $\begin{array}{c}\text { Higher systolic blood pressure } \\
\text { at } 4 \text { weeks of age }\end{array}$ & $\mathrm{M}$ and $\mathrm{F}$ & [80] \\
\hline & rat & $\begin{array}{l}\text { in utero } \\
\text { and } \\
\text { lactation }\end{array}$ & Increased oxidative stress & $\begin{array}{c}\text { not } \\
\text { available }\end{array}$ & [81] \\
\hline & rat & in utero & $\begin{array}{l}\text { Increased systolic blood } \\
\text { pressure, impaired recovery of } \\
\text { left ventricular developed } \\
\text { pressure after ischaemia } \\
\text { (Langendorff) }\end{array}$ & $\mathrm{M}$ and $\mathrm{F}$ & [82] \\
\hline & rat & in utero & $\begin{array}{c}\text { Hypertension and renal } \\
\text { dysfunction }\end{array}$ & $\mathrm{M}$ and $\mathrm{F}$ & [83] \\
\hline & goat & $\begin{array}{c}\text { Late } \\
\text { gestation }\end{array}$ & $\begin{array}{l}\text { Reduced heart and body } \\
\text { weight at birth }\end{array}$ & M & [84] \\
\hline $\begin{array}{l}\text { Low protein } \\
\text { and post- } \\
\text { natal catch- } \\
\text { up growth }\end{array}$ & Rat & in utero & $\begin{array}{c}\text { Cardiac DNA damage and } \\
\text { oxidative stress }\end{array}$ & $\mathrm{M}$ & {$[24,25]$} \\
\hline
\end{tabular}

Table 1: Experimental evidence of the effects of maternal under and overnutrition on the offspring cardiovascular system.

\section{DIET AND CARDIOVASCULAR EPIGENOMICS}

Current diet is thought to be a potent epigenetic modifier. However, there is also now evidence to suggest that early life exposure to suboptimal nutrition can permanently affect transcriptional regulation through epigenetic alterations, and this is thought to contribute to the long-lasting consequences on 
offspring health [85]. Epigenetic regulation of the genome in mammals is mediated by DNA methylation, histone protein modification and epigenetic related RNA-based mechanisms (miRNAs, piRNAs, tRNA fragments and long non-coding RNAs). During embryogenesis the epigenetic information is believed to be globally erased, and subsequently re-established after embryo implantation. The timing and nature of the epigenetic modification will define different cell phenotypes. All the aforementioned epigenetic marks are sensitive and modifiable upon dietary challenges in utero [86]. Whether the effects are tissue specific or global will depend on the timing of the challenge. If it occurs early (when only a few cells exist) prior to tissue differentiation, then these changes will be present in all tissues within the body (meta-stable epialleles - see DNA methylation). The impact of the in utero environment (F0) on the transmission of certain metabolic traits to the F1 generation is an example of "inter-generational" inheritance. In contrast, "trans-generational" transmission requires the phenotype manifestation to occur in absence of the original stimuli which caused it, nutrition in this case (F2 for inheritance via paternal line; F3 for inheritance via maternal line) [87].

Although epigenetic regulation of gene expression has been extensively implicated in the pathophysiology of CVD, evidence for the existence of a causative link between nutrition, epigenetics and developmental programming of CVD is still limited. More evidence exists for the influence of early life nutrition on epigenetic regulation of gene transcription in adipose tissue, brain, liver and pancreas $[85,86]$.

\section{DNA methylation}

DNA methylation is by far the best characterized epigenetic modification. Changes in DNA methylation patterns have been identified in human patients with heart failure [88] and dilated cardiomyopathy [89]. However in these studies it is impossible to dissect out whether these changes occurred as a consequence of the disease state or are causative in its development. Recent analysis of the DNA methylome of newborn, healthy adult and adult failing cardiomyocytes revealed a prominent role for DNA methylation in regulating various aspect of cardiac biology, from heart development to disease [90].

Human studies have contributed significantly to the evidence for a link between exposure to periconceptional cues and permanent changes in DNA methylation. Studies from the Dutch Famine Birth Cohort Study [91] showed low methylation levels at various loci involved in growth and metabolism in individuals exposed to famine peri-conceptionally, and not during gestation [92, 93]. In mammals, the degree of DNA methylation of certain genomic regions called metastable epialleles (MEs) is determined at the early stages of embryonic development, and is susceptible to peri-conceptional disturbances which will ultimately be present in all tissues potentially affecting their functionality [94]. The maternal nutritional status of Gambian women, which are known to undergo seasonal fluctuations in nutrient intake, significantly influenced the DNA methylation status of specific MEs in offspring hair follicles and lymphocytes post-natally [95**, 96], demonstrating that maternal nutrition can permanently shape the fetal epigenome. As mentioned above, maternal bariatric surgery in obese women improves 
offspring cardiometabolic health [43]. Two independent studies have reported that babies born to the same obese mother before and after bariatric surgery display alterations in the methylome of genes involved respectively in glucose regulation, inflammation, and vascular disease [43], or in diabetes, obesity and insulin signalling [97]*. Peroxisome proliferator-activated receptor alpha (PPAR $\alpha$ ) promoter methylation was reduced in adult and neonatal rat hearts exposed to maternal protein restriction, and this was associated with increased mRNA levels of PPAR $\alpha$ only in adult hearts [98]. Oxidative stress is known to interfere with DNA methylation. High levels of reactive oxygen species (ROS) and oxidative stress are features of pregnancy complications (such as pre-eclampsia), and can induce permanent changes in transcription [99]. Epigenetic repression by DNA methylation of protein kinase $\mathrm{C} \varepsilon$ by ROS was reported in rat fetal hearts and increased ischemia susceptibility in adult male offspring, which was restored by treatment with a ROS scavenger [100]. Similarly, exposure to maternal caloric restriction caused impaired endothelium-dependent pulmonary artery vasodilation with alterations in the DNA methylation profile of lung tissue in 12-week old male offspring; both artery dysfunction and DNA methylation profile were restored after maternal anti-oxidant treatment [101].

\section{Histone modifications}

Acetylation of histone tails by histone acetyl transferases causes de-compaction of the nucleosomes and promotes transcription. The role of histone deacetylase enzymes (HDAC) in cardiovascular biology has been well characterized [102], as well as their potential as therapeutic targets of heart disease [103]. In vivo HDAC inhibitor treatment attenuated cardiac hypertrophy [104] and fibrosis [105] in hearts exposed to hypertrophic stimuli. HDAC1 and HDAC2 null mice developed dilated cardiomyopathy [106], whereas cardiac-specific deletion of HDAC3 resulted in severe cardiac hypertrophy [107]. Also, mice lacking either HDAC5 or HDAC9 spontaneously developed cardiac hypertrophy [108]. It is well established that dietary challenges in utero and post-natally modify the chromatin histones code in a wide variety of tissues [86]; however, not much evidence has been provided so far regarding the impact of in utero suboptimal nutrition on the epigenetic control in the heart through changes in histone modification.

\section{Small non-coding RNAs (snRNAs)}

Whether poor maternal nutrition can alter and shape offspring metabolic profile and organ function through alterations in snRNAs such as miRNAs, piRNAs and tRNA fragments is a very intense area of research. A few labs have identified miRNAs as potential inter-generational mediators of the fetal response to maternal nutrition in offspring organs of obese or undernourished mothers such as liver [109-111], adipose tissue [112] and skeletal muscle [113]. In the heart, alterations in miRNA profile was shown in the heart of fetal baboons born to high fat/high fructose-diet fed mothers [114]*. Among the dysregulated miRNAs, fifteen were previously associated with CVD in human and animal models and were shown to regulate cellular death, growth, and proliferation. MiR-133a was up-regulated in the 
heart of offspring exposed to a maternal obesogenic diet during gestation and lactation [60]. Hearts from those mice presented pathological cardiac hypertrophy [60] and early onset of cardiac dysfunction [59] when compared to age-matched controls. In humans, an obesogenic intrauterine environment perturbs the amniotic miRNA profile, with possible consequences for placental function and fetal growth [115]. Also, a recent study implicates miRNAs as modulators of pre- and post-natal growth of babies born to mothers with gestational diabetes mellitus [116]*. These studies provide evidence that maternal overnutrition can alter the miRNA profile in different offspring tissues, and can potentially influence their long-term health.

Important insights into the role of snRNAs in the programming of metabolic diseases have recently emerged from studies addressing the impact of paternal nutrition. A suboptimal dietary regime in the father, modifies the snRNA profile in mature sperm of humans and mice, making snRNAs excellent candidates for trans-generational epigenetic inheritance of metabolic traits. Mechanisms of inheritance through the paternal line can be studied in absence of the in utero confounding effects. Only recently, an exciting series of papers have proposed that in mice alterations in the sperm miRNA [117-119]*, tRNA fragments [120, 121] and piRNA [119] profile can induce metabolic and behavioural perturbations in the progeny. Sperm of mice fed a western diet showed an altered piRNAs profile $[119]^{* *}$. Also, bariatric surgery in obese individuals modified the abundance of miRNAs, piRNAs and tRNA fragments in the sperm [122]**, suggesting that diet and metabolic state can interfere with progeny metabolic health through paternally inherited RNA-based mechanisms, and that these mechanisms are likely to be conserved in humans. MiRNA injection in naïve zygotes was able to initiate in the offspring metabolic alterations similar to a high fat diet-induced phenotype [119], whereas transfer of tRNA fragments isolated from mature sperm into 2-cell embryos induced severe glucose intolerance in 7-week old mice [120]**. Whether maternal diet could modify snRNA expression in the oocyte is unknown. MiRNA function seems to be globally suppressed in the murine female germline [123]; however, components of the piRNA-pathway have been shown to be active in the bovine, macaque, and human ovaries, as well as in the early embryo [124]. The oocyte contribution to the epigenetic transmission of metabolic diseases is still unexplored and perhaps difficult to assess directly in presence of other modalities of inheritance through the female germline (e.g. mitochondria). Oocytes of obese mice display oxidative stress-induced defects in mitochondrial function, as well as altered methylation levels [125], which may contribute to the programming of altered metabolic phenotypes post-natally [126]. Recent work suggests that in mice the insulin resistant phenotype is mainly acquired through the maternal line [127]*, but the underlying epigenetic mechanisms are not known.

\section{CONCLUSIONS}

It is an exciting scientific moment for the developmental programming field. Extensive evidence has been provided in the last decades of a direct causative link between a suboptimal intrauterine environment and development of cardiovascular diseases in humans and animal models. Here, we have 
summarized the evidence regarding how diet and metabolic disturbances in early life can affect the offspring epigenome rendering the progeny more prone to cardiovascular diseases (figure 1). Despite much effort that has been exerted so far, we are only starting to understand the epigenetic contribution towards this process. Improving our knowledge of the molecular pathways and the modality of programming of cardiometabolic disease by suboptimal early life is demanding, in order to design rational intervention strategies for the mother and the baby.

\section{AKNOWLEDGMENTS}

We thank the British Heart Foundation and Medical Research Council for funding our research.

\section{FINANCIAL SUPPORT AND SPONSORSHIP}

Our research is supported by the Medical Research Council (MRC; MC_UU_12012/4) and the British Heart Foundation (FS/12/64/30001 and PG/14/20/ 30769).

\section{CONFLICTS OF INTEREST}

There are no conflicts of interest.

\section{REFERENCES:}

References of special (*) or outstanding (**) interest.

[1] Barker DJ. Maternal nutrition, fetal nutrition, and disease in later life. Nutrition 1997; 13:807-813. [2] Tarry-Adkins JL, Ozanne SE. The impact of early nutrition on the ageing trajectory. Proc Nutr Soc 2014; 73:289-301.

[3] Demicheva E, Crispi F. Long-term follow-up of intrauterine growth restriction: cardiovascular disorders. Fetal Diagn Ther 2014; 36:143-153.

[4] Pettitt DJ, Jovanovic L. Birth weight as a predictor of type 2 diabetes mellitus: the U-shaped curve. Curr Diab Rep 2001; 1:78-81.

[5] Barker DJ, Winter PD, Osmond C et al. Weight in infancy and death from ischaemic heart disease. Lancet 1989; 2:577-580.

[6] Risnes KR, Vatten L, Baker JL et al. Birthweight and mortality in adulthood: a systematic review and meta-analysis. Int J Epidemiol 2011; 40:647-661.

[7] Eriksson JG, Forsén T, Tuomilehto J et al. Catch-up growth in childhood and death from coronary heart disease: longitudinal study. BMJ 1999; 318:427-431.

[8] Velkoska E, Cole TJ, Dean RG et al. Early undernutrition leads to long-lasting reductions in body weight and adiposity whereas increased intake increases cardiac fibrosis in male rats. J Nutr 2008; 138:1622-1627.

[9] Comas M, Crispi F, Cruz-Martinez R et al. Usefulness of myocardial tissue Doppler vs conventional echocardiography in the evaluation of cardiac dysfunction in early-onset intrauterine growth restriction. Am J Obstet Gynecol 2010; 203:45.e41-47.

[10] Sehgal A, Doctor T, Menahem S. Cardiac function and arterial biophysical properties in small for gestational age infants: postnatal manifestations of fetal programming. J Pediatr 2013; 163:12961300 . 
[11] Cohen E, Wong FY, Horne RS, Yiallourou SR. Intrauterine growth restriction: impact on cardiovascular development and function throughout infancy. Pediatr Res 2016.

[12] Porrello ER, Widdop RE, Delbridge LM. Early origins of cardiac hypertrophy: does cardiomyocyte attrition programme for pathological 'catch-up' growth of the heart? Clin Exp Pharmacol Physiol 2008; 35:1358-1364.

[13] Baird J, Fisher D, Lucas P et al. Being big or growing fast: systematic review of size and growth in infancy and later obesity. BMJ 2005; 331:929.

[14] Gittner LS, Ludington-Hoe SM, Haller HS. Utilising infant growth to predict obesity status at 5 years. J Paediatr Child Health 2013; 49:564-574.

[15] Lucas A, Bishop NJ, King FJ, Cole TJ. Randomised trial of nutrition for preterm infants after discharge. Arch Dis Child 1992; 67:324-327.

[16] Lewis DS, Bertrand HA, McMahan CA et al. Influence of preweaning food intake on body composition of young adult baboons. Am J Physiol 1989; 257:R1128-1135.

[17] Lewis DS, Bertrand HA, McMahan CA et al. Preweaning food intake influences the adiposity of young adult baboons. J Clin Invest 1986; 78:899-905.

[18] Habbout A, Li N, Rochette L, Vergely C. Postnatal overfeeding in rodents by litter size reduction induces major short- and long-term pathophysiological consequences. J Nutr 2013; 143:553-562.

[19] Elks CE, Heude B, de Zegher F et al. Associations between genetic obesity susceptibility and early postnatal fat and lean mass: an individual participant meta-analysis. JAMA Pediatr 2014; 168:11221130.

[20] Vieira AK, Soares VM, Bernardo AF et al. Overnourishment during lactation induces metabolic and haemodynamic heart impairment during adulthood. Nutr Metab Cardiovasc Dis 2015; 25:1062-1069.

[21] Bernardo AF, Cortez E, Neves FA et al. Overnutrition during lactation leads to impairment in insulin signaling, up-regulation of GLUT1 and increased mitochondrial carbohydrate oxidation in heart of weaned mice. J Nutr Biochem 2015.

*This study demonstrates that over-feeding over a short period of time (lactation) causes early onset of cardiac remodelling (hypertrophy and fibrosis), as well as a metabolic switch to glucose oxidation, which takes place in hypertrophic and failing hearts.

[22] Pereira RO, Moreira AS, de Carvalho L, Moura AS. Overfeeding during lactation modulates insulin and leptin signaling cascade in rats' hearts. Regul Pept 2006; 136:117-121.

[23] Habbout A, Guenancia C, Lorin J et al. Postnatal overfeeding causes early shifts in gene expression in the heart and long-term alterations in cardiometabolic and oxidative parameters. PLoS One 2013; 8:e56981.

[24] Tarry-Adkins JL, Blackmore HL, Martin-Gronert MS et al. Coenzyme Q10 prevents accelerated cardiac aging in a rat model of poor maternal nutrition and accelerated postnatal growth. Mol Metab 2013; 2:480-490.

[25] Tarry-Adkins JL, Martin-Gronert MS, Fernandez-Twinn DS et al. Poor maternal nutrition followed by accelerated postnatal growth leads to alterations in DNA damage and repair, oxidative and nitrosative stress, and oxidative defense capacity in rat heart. FASEB J 2013; 27:379-390.

[26] Petry CJ, Dorling MW, Pawlak DB et al. Diabetes in old male offspring of rat dams fed a reduced protein diet. Int J Exp Diabetes Res 2001; 2:139-143.

[27] Ozanne SE, Hales CN. Lifespan: catch-up growth and obesity in male mice. Nature 2004; 427:411412.

[28] Roseboom TJ, van der Meulen JH, Osmond C et al. Coronary heart disease after prenatal exposure to the Dutch famine, 1944-45. Heart 2000; 84:595-598.

[29] Ravelli AC, van der Meulen JH, Michels RP et al. Glucose tolerance in adults after prenatal exposure to famine. Lancet 1998; 351:173-177.

[30] Lisowski LA, Verheijen PM, Copel JA et al. Congenital heart disease in pregnancies complicated by maternal diabetes mellitus. An international clinical collaboration, literature review, and metaanalysis. Herz 2010; 35:19-26. 
[31] Lisowski LA, Verheijen PM, De Smedt MM et al. Altered fetal circulation in type-1 diabetic pregnancies. Ultrasound Obstet Gynecol 2003; 21:365-369.

[32] Gardiner HM, Pasquini L, Wolfenden J et al. Increased periconceptual maternal glycated haemoglobin in diabetic mothers reduces fetal long axis cardiac function. Heart 2006; 92:1125-1130.

[33] Corrigan N, Brazil DP, McAuliffe F. Fetal cardiac effects of maternal hyperglycemia during pregnancy. Birth Defects Res A Clin Mol Teratol 2009; 85:523-530.

[34] Odegård RA, Vatten L, Nilsen ST et al. Preeclampsia and fetal growth. Obstet Gynecol 2000; 96:950-955.

[35] Davis EF, Newton L, Lewandowski AJ et al. Pre-eclampsia and offspring cardiovascular health: mechanistic insights from experimental studies. Clin Sci (Lond) 2012; 123:53-72.

[36] Reynolds RM, Allan KM, Raja EA et al. Maternal obesity during pregnancy and premature mortality from cardiovascular event in adult offspring: follow-up of 1323275 person years. BMJ 2013; 347:f4539.

[37] Eriksson JG, Sandboge S, Salonen MK et al. Long-term consequences of maternal overweight in pregnancy on offspring later health: findings from the Helsinki Birth Cohort Study. Ann Med 2014; 46:434-438.

[38] Ryckman KK, Borowski KS, Parikh NI, Saftlas AF. Pregnancy Complications and the Risk of Metabolic Syndrome for the Offspring. Curr Cardiovasc Risk Rep 2013; 7:217-223.

[39] Catalano PM, Presley L, Minium J, Hauguel-de Mouzon S. Fetuses of obese mothers develop insulin resistance in utero. Diabetes Care 2009; 32:1076-1080.

[40] Ece I, Uner A, Balli S et al. The effects of pre-pregnancy obesity on fetal cardiac functions. Pediatr Cardiol 2014; 35:838-843.

[41] Ingul CB, Lorås L, Tegnander E et al. Maternal obesity affects foetal myocardial function already in first trimester. Ultrasound Obstet Gynecol 2015.

*This paper demonstrated that human fetuses of obese mothers developed fetal myocardial dysfunction as early as 14 weeks, confirming how a suboptimal maternal environment can negatively influence fetal cardioascular health.

[42] Smith J, Cianflone K, Biron S et al. Effects of maternal surgical weight loss in mothers on intergenerational transmission of obesity. J Clin Endocrinol Metab 2009; 94:4275-4283.

[43] Guénard F, Deshaies $Y$, Cianflone $\mathrm{K}$ et al. Differential methylation in glucoregulatory genes of offspring born before vs. after maternal gastrointestinal bypass surgery. Proc Natl Acad Sci U S A 2013; 110:11439-11444.

**This unique study reported that bariatric surgery in the mother can restore the detrimental metabolic effect programmed by an obese uterine enviornment; this was also associated with pervasive changes in the methylome and transcriptome of the offspring relative to glucoregulatory, inflammatory, and vascular disease genes.

[44] Elahi MM, Cagampang FR, Mukhtar D et al. Long-term maternal high-fat feeding from weaning through pregnancy and lactation predisposes offspring to hypertension, raised plasma lipids and fatty liver in mice. Br J Nutr 2009; 102:514-519.

[45] Liang C, Oest ME, Prater MR. Intrauterine exposure to high saturated fat diet elevates risk of adult-onset chronic diseases in C57BL/6 mice. Birth Defects Res B Dev Reprod Toxicol 2009; 86:377384.

[46] Mdaki KS, Larsen TD, Wachal AL et al. Maternal high-fat diet impairs cardiac function in offspring of diabetic pregnancy through metabolic stress and mitochondrial dysfunction. Am J Physiol Heart Circ Physiol 2016; 310:H681-692.

[47] Koukkou E, Ghosh P, Lowy C, Poston L. Offspring of normal and diabetic rats fed saturated fat in pregnancy demonstrate vascular dysfunction. Circulation 1998; 98:2899-2904.

[48] Khan IY, Taylor PD, Dekou V et al. Gender-linked hypertension in offspring of lard-fed pregnant rats. Hypertension 2003; 41:168-175.

[49] Ghosh P, Bitsanis D, Ghebremeskel K et al. Abnormal aortic fatty acid composition and small artery function in offspring of rats fed a high fat diet in pregnancy. J Physiol 2001; 533:815-822. 
[50] Taylor PD, Khan IY, Hanson MA, Poston L. Impaired EDHF-mediated vasodilatation in adult offspring of rats exposed to a fat-rich diet in pregnancy. J Physiol 2004; 558:943-951.

[51] Khan I, Dekou V, Hanson M et al. Predictive adaptive responses to maternal high-fat diet prevent endothelial dysfunction but not hypertension in adult rat offspring. Circulation 2004; 110:1097-1102. [52] Khan IY, Dekou V, Douglas G et al. A high-fat diet during rat pregnancy or suckling induces cardiovascular dysfunction in adult offspring. Am J Physiol Regul Integr Comp Physiol 2005; 288:R127133.

[53] Xue Q, Chen P, Li X et al. Maternal High-Fat Diet Causes a Sex-Dependent Increase in AGTR2 Expression and Cardiac Dysfunction in Adult Male Rat Offspring. Biol Reprod 2015; 93:49.

*The authors provide evidence that male rats (but not females) born to high fat diet-fed mothers developed increased susceptibility to ischaemia-repurfusion, and propose a role for AGTR2 in the programming of the cardiac phenotype.

[54] Armitage JA, Lakasing L, Taylor PD et al. Developmental programming of aortic and renal structure in offspring of rats fed fat-rich diets in pregnancy. J Physiol 2005; 565:171-184.

[55] Huang Y, Yan X, Zhao JX et al. Maternal obesity induces fibrosis in fetal myocardium of sheep. Am J Physiol Endocrinol Metab 2010; 299:E968-975.

[56] Wang J, Ma H, Tong $\mathrm{C}$ et al. Overnutrition and maternal obesity in sheep pregnancy alter the JNKIRS-1 signaling cascades and cardiac function in the fetal heart. FASEB J 2010; 24:2066-2076.

[57] Fan X, Turdi S, Ford SP et al. Influence of gestational overfeeding on cardiac morphometry and hypertrophic protein markers in fetal sheep. J Nutr Biochem 2011; 22:30-37.

[58] Fan L, Lindsley SR, Comstock SM et al. Maternal high-fat diet impacts endothelial function in nonhuman primate offspring. Int J Obes (Lond) 2013; 37:254-262.

[59] Blackmore HL, Niu Y, Fernandez-Twinn DS et al. Maternal diet-induced obesity programs cardiovascular dysfunction in adult male mouse offspring independent of current body weight. Endocrinology 2014; 155:3970-3980.

*This paper demonstrates that male offspring of obese mothers developed increased left ventricular end-diastolic pressure and impaired ventricular relaxation in adulthood.

[60] Fernandez-Twinn DS, Blackmore HL, Siggens L et al. The programming of cardiac hypertrophy in the offspring by maternal obesity is associated with hyperinsulinemia, AKT, ERK, and mTOR activation. Endocrinology 2012; 153:5961-5971.

[61] Samuelsson AM, Matthews PA, Argenton M et al. Diet-induced obesity in female mice leads to offspring hyperphagia, adiposity, hypertension, and insulin resistance: a novel murine model of developmental programming. Hypertension 2008; 51:383-392.

[62] Samuelsson AM, Morris A, Igosheva $\mathrm{N}$ et al. Evidence for sympathetic origins of hypertension in juvenile offspring of obese rats. Hypertension 2010; 55:76-82.

[63] Kawamura $\mathrm{M}$, Itoh $\mathrm{H}$, Yura $\mathrm{S}$ et al. Undernutrition in utero augments systolic blood pressure and cardiac remodeling in adult mouse offspring: possible involvement of local cardiac angiotensin system in developmental origins of cardiovascular disease. Endocrinology 2007; 148:1218-1225.

[64] Kawamura M, Itoh H, Yura S et al. Isocaloric high-protein diet ameliorates systolic blood pressure increase and cardiac remodeling caused by maternal caloric restriction in adult mouse offspring. Endocr J 2009; 56:679-689.

[65] Torrens C, Hanson MA, Gluckman PD, Vickers MH. Maternal undernutrition leads to endothelial dysfunction in adult male rat offspring independent of postnatal diet. Br J Nutr 2009; 101:27-33.

[66] Woodall SM, Johnston BM, Breier BH, Gluckman PD. Chronic maternal undernutrition in the rat leads to delayed postnatal growth and elevated blood pressure of offspring. Pediatr Res 1996; 40:438443.

[67] Ponzio BF, Carvalho MH, Fortes ZB, do Carmo Franco M. Implications of maternal nutrient restriction in transgenerational programming of hypertension and endothelial dysfunction across F1F3 offspring. Life Sci 2012; 90:571-577.

[68] Corstius HB, Zimanyi MA, Maka $\mathrm{N}$ et al. Effect of intrauterine growth restriction on the number of cardiomyocytes in rat hearts. Pediatr Res 2005; 57:796-800. 
[69] Harvey TJ, Murphy RM, Morrison JL, Posterino GS. Maternal Nutrient Restriction Alters Ca2+ Handling Properties and Contractile Function of Isolated Left Ventricle Bundles in Male But Not Female Juvenile Rats. PLoS One 2015; 10:e0138388.

*This paper identified $\mathrm{Ca} 2+$ signalling as target of programming by maternal caloric restriction; consistent with previous work [52], male offspring were more affected than females.

[70] Xu Y, Williams SJ, O'Brien D, Davidge ST. Hypoxia or nutrient restriction during pregnancy in rats leads to progressive cardiac remodeling and impairs postischemic recovery in adult male offspring. FASEB J 2006; 20:1251-1253.

[71] Almeida JR, Mandarim-de-Lacerda CA. Maternal gestational protein-calorie restriction decreases the number of glomeruli and causes glomerular hypertrophy in adult hypertensive rats. Am J Obstet Gynecol 2005; 192:945-951.

[72] Gilbert JS, Lang AL, Grant AR, Nijland MJ. Maternal nutrient restriction in sheep: hypertension and decreased nephron number in offspring at 9 months of age. J Physiol 2005; 565:137-147.

[73] Vonnahme KA, Hess BW, Hansen TR et al. Maternal undernutrition from early- to mid-gestation leads to growth retardation, cardiac ventricular hypertrophy, and increased liver weight in the fetal sheep. Biol Reprod 2003; 69:133-140.

[74] Ge W, Hu N, George LA et al. Maternal nutrient restriction predisposes ventricular remodeling in adult sheep offspring. J Nutr Biochem 2013; 24:1258-1265.

[75] Watkins AJ, Lucas ES, Torrens C et al. Maternal low-protein diet during mouse pre-implantation development induces vascular dysfunction and altered renin-angiotensin-system homeostasis in the offspring. Br J Nutr 2010; 103:1762-1770.

[76] Asopa S, Cagampang FR, Anthony FW et al. Effect of a low-protein diet during pregnancy on expression of genes involved in cardiac hypertrophy in fetal and adult mouse offspring. J Dev Orig Health Dis 2010; 1:371-375.

[77] Brawley L, Itoh S, Torrens C et al. Dietary protein restriction in pregnancy induces hypertension and vascular defects in rat male offspring. Pediatr Res 2003; 54:83-90.

[78] Fernandez-Twinn DS, Ekizoglou S, Wayman A et al. Maternal low-protein diet programs cardiac beta-adrenergic response and signaling in 3-mo-old male offspring. Am J Physiol Regul Integr Comp Physiol 2006; 291:R429-436.

[79] Barros MA, De Brito Alves JL, Nogueira VO et al. Maternal low-protein diet induces changes in the cardiovascular autonomic modulation in male rat offspring. Nutr Metab Cardiovasc Dis 2015; 25:123130.

[80] Langley-Evans SC, Phillips GJ, Jackson AA. In utero exposure to maternal low protein diets induces hypertension in weanling rats, independently of maternal blood pressure changes. Clin Nutr 1994; 13:319-324.

[81] Nascimento L, Freitas CM, Silva-Filho R et al. The effect of maternal low-protein diet on the heart of adult offspring: role of mitochondria and oxidative stress. Appl Physiol Nutr Metab 2014; 39:880887.

[82] Elmes MJ, Gardner DS, Langley-Evans SC. Fetal exposure to a maternal low-protein diet is associated with altered left ventricular pressure response to ischaemia-reperfusion injury. Br J Nutr 2007; 98:93-100.

[83] Nwagwu MO, Cook A, Langley-Evans SC. Evidence of progressive deterioration of renal function in rats exposed to a maternal low-protein diet in utero. Br J Nutr 2000; 83:79-85.

[84] He ZX, Wu DQ, Sun ZH et al. Protein or energy restriction during late gestation alters fetal growth and visceral organ mass: an evidence of intrauterine programming in goats. Anim Reprod Sci 2013; 137:177-182.

[85] Lee HS. Impact of Maternal Diet on the Epigenome during In Utero Life and the Developmental Programming of Diseases in Childhood and Adulthood. Nutrients 2015; 7:9492-9507.

[86] Jiménez-Chillarón JC, Díaz R, Martínez D et al. The role of nutrition on epigenetic modifications and their implications on health. Biochimie 2012; 94:2242-2263. 
[87] Dias BG, Ressler KJ. Experimental evidence needed to demonstrate inter- and trans-generational effects of ancestral experiences in mammals. Bioessays 2014; 36:919-923.

[88] Movassagh M, Vujic A, Foo R. Genome-wide DNA methylation in human heart failure. Epigenomics 2011; 3:103-109.

[89] Haas J, Frese KS, Park YJ et al. Alterations in cardiac DNA methylation in human dilated cardiomyopathy. EMBO Mol Med 2013; 5:413-429.

[90] Gilsbach R, Preissl S, Grüning BA et al. Dynamic DNA methylation orchestrates cardiomyocyte development, maturation and disease. Nat Commun 2014; 5:5288.

[91] Lumey LH, Stein AD, Kahn HS et al. Cohort profile: the Dutch Hunger Winter families study. Int J Epidemiol 2007; 36:1196-1204.

[92] Tobi EW, Lumey LH, Talens RP et al. DNA methylation differences after exposure to prenatal famine are common and timing- and sex-specific. Hum Mol Genet 2009; 18:4046-4053.

[93] Heijmans BT, Tobi EW, Stein AD et al. Persistent epigenetic differences associated with prenatal exposure to famine in humans. Proc Natl Acad Sci U S A 2008; 105:17046-17049.

[94] Rakyan VK, Blewitt ME, Druker R et al. Metastable epialleles in mammals. Trends Genet 2002; 18:348-351.

[95] Dominguez-Salas P, Moore SE, Baker MS et al. Maternal nutrition at conception modulates DNA methylation of human metastable epialleles. Nat Commun 2014; 5:3746.

**This paper demonstrates that offspring conceived by mothers with a naturally protein-restricted diet had higher CpG methylation at specific metastable epialleles; importantly, maternal BMI, vitamin B2, homocysteine and cysteine levels at the time of conception predicted the DNA methylation state of offspring tissues.

[96] Waterland RA, Kellermayer R, Laritsky E et al. Season of conception in rural gambia affects DNA methylation at putative human metastable epialleles. PLoS Genet 2010; 6:e1001252.

[97] Berglind D, Müller P, Willmer $\mathrm{M}$ et al. Differential methylation in inflammation and type 2 diabetes genes in siblings born before and after maternal bariatric surgery. Obesity (Silver Spring) 2016; 24:250261.

*This paper demonstrates that siblings born before and after bariatric surgery display differential methylation in genes involved in insulin receptor signaling, type 2 diabetes signaling, and leptin signaling in obesity, including IGF2 which has been shown to be influenced by matrnal diet in other studies. (St-Pierre J, Epigenetics 2012;7:1125-1132. 28; [91])

[98] Slater-Jefferies JL, Lillycrop KA, Townsend PA et al. Feeding a protein-restricted diet during pregnancy induces altered epigenetic regulation of peroxisomal proliferator-activated receptor- $\alpha$ in the heart of the offspring. J Dev Orig Health Dis 2011; 2:250-255.

[99] Ávila JG, Echeverri I, de Plata CA, Castillo A. Impact of oxidative stress during pregnancy on fetal epigenetic patterns and early origin of vascular diseases. Nutr Rev 2015; 73:12-21.

[100] Patterson AJ, Xiao D, Xiong $\mathrm{F}$ et al. Hypoxia-derived oxidative stress mediates epigenetic repression of $\mathrm{PKC} \varepsilon$ gene in foetal rat hearts. Cardiovasc Res 2012; 93:302-310.

[101] Rexhaj E, Bloch J, Jayet PY et al. Fetal programming of pulmonary vascular dysfunction in mice: role of epigenetic mechanisms. Am J Physiol Heart Circ Physiol 2011; 301:H247-252.

[102] Tingare A, Thienpont B, Roderick HL. Epigenetics in the heart: the role of histone modifications in cardiac remodelling. Biochem Soc Trans 2013; 41:789-796.

[103] McKinsey TA. Therapeutic potential for HDAC inhibitors in the heart. Annu Rev Pharmacol Toxicol 2012; 52:303-319.

[104] Trivedi CM, Luo Y, Yin Z et al. Hdac2 regulates the cardiac hypertrophic response by modulating Gsk3 beta activity. Nat Med 2007; 13:324-331.

[105] lyer A, Fenning A, Lim J et al. Antifibrotic activity of an inhibitor of histone deacetylases in DOCAsalt hypertensive rats. Br J Pharmacol 2010; 159:1408-1417.

[106] Montgomery RL, Davis CA, Potthoff MJ et al. Histone deacetylases 1 and 2 redundantly regulate cardiac morphogenesis, growth, and contractility. Genes Dev 2007; 21:1790-1802. 
[107] Montgomery RL, Potthoff MJ, Haberland M et al. Maintenance of cardiac energy metabolism by histone deacetylase 3 in mice. J Clin Invest 2008; 118:3588-3597.

[108] Chang S, McKinsey TA, Zhang CL et al. Histone deacetylases 5 and 9 govern responsiveness of the heart to a subset of stress signals and play redundant roles in heart development. Mol Cell Biol 2004; 24:8467-8476.

[109] Benatti RO, Melo AM, Borges FO et al. Maternal high-fat diet consumption modulates hepatic lipid metabolism and microRNA-122 (miR-122) and microRNA-370 (miR-370) expression in offspring. Br J Nutr 2014; 111:2112-2122.

[110] Nicholas LM, Rattanatray L, Maclaughlin SM et al. Differential effects of maternal obesity and weight loss in the periconceptional period on the epigenetic regulation of hepatic insulin-signaling pathways in the offspring. FASEB J 2013.

[111] Zhang J, Zhang F, Didelot $X$ et al. Maternal high fat diet during pregnancy and lactation alters hepatic expression of insulin like growth factor-2 and key microRNAs in the adult offspring. BMC Genomics 2009; 10:478.

[112] Fernandez-Twinn DS, Alfaradhi MZ, Martin-Gronert MS et al. Downregulation of IRS-1 in adipose tissue of offspring of obese mice is programmed cell-autonomously through post-transcriptional mechanisms. Mol Metab 2014; 3:325-333.

[113] Yan X, Huang Y, Zhao JX et al. Maternal obesity downregulates microRNA let-7g expression, a possible mechanism for enhanced adipogenesis during ovine fetal skeletal muscle development. Int J Obes (Lond) 2013; 37:568-575.

[114] Maloyan A, Muralimanoharan S, Huffman S et al. Identification and comparative analyses of myocardial miRNAs involved in the fetal response to maternal obesity. Physiol Genomics 2013; 45:889-900.

*This paper provides proof of concept that gestational exposure to maternal obesity alters the microRNA profile of fetal offspring hearts.

[115] Nardelli C, laffaldano L, Ferrigno $\mathrm{M}$ et al. Characterization and predicted role of the microRNA expression profile in amnion from obese pregnant women. Int J Obes (Lond) 2013.

[116] Carreras-Badosa G, Bonmatí A, Ortega FJ et al. Altered Circulating miRNA Expression Profile in Pregestational and Gestational Obesity. J Clin Endocrinol Metab 2015; 100:E1446-1456.

*This paper identifies miR-340, miR-423-5p, and miR-652 as independent predictors of placental weight or birthweight, and suggests a role for miRNAs as potential early markers for pre- and postnatal growth.

[117] Rodgers AB, Morgan CP, Leu NA, Bale TL. Transgenerational epigenetic programming via sperm microRNA recapitulates effects of paternal stress. Proc Natl Acad Sci U S A 2015; 112:13699-13704.

[118] Rodgers AB, Morgan CP, Bronson SL et al. Paternal stress exposure alters sperm microRNA content and reprograms offspring HPA stress axis regulation. J Neurosci 2013; 33:9003-9012.

*Rodgers et $a l$. identified nine specific miRs that were significantly increased in the sperm of male mice upon stress exposure; a similar stress response was observed in adult offspring generated from 2-cell zygotes injected with the 9 miRs [115].

[119] Grandjean V, Fourré S, De Abreu DA et al. RNA-mediated paternal heredity of diet-induced obesity and metabolic disorders. Sci Rep 2015; 5:18193.

**The authors report differential expression of microRNAs and piRNAs in the sperm of male mice exposed to a high-fat diet; moreover, injection of miR-19b into one-cell embryos was sufficient to induce obesity and a diabetogenic phenotype in the offspring.

[120] Chen $Q$, Yan M, Cao Z et al. Sperm tsRNAs contribute to intergenerational inheritance of an acquired metabolic disorder. Science 2016; 351:397-400.

**This paper demonstrated that transfer of sperm tRNAs isolated from mice fed a high-fat diet into control oocytes was able to program a diet-induced metabolic disease in adult offspring; this is very relevant in relation to pervious work reporting changes in tRNA abundance in human sperm before and after bariatric surgery [121]. 
[121] Sharma U, Conine CC, Shea JM et al. Biogenesis and function of tRNA fragments during sperm maturation and fertilization in mammals. Science 2016; 351:391-396.

[122] Donkin I, Versteyhe S, Ingerslev LR et al. Obesity and Bariatric Surgery Drive Epigenetic Variation of Spermatozoa in Humans. Cell Metab 2016; 23:369-378.

**Analysis of sperm from obese humans revealed significant alterations in the abundance of piRNA, tRNA, and microRNA profile before and after bariatric surgery, suggesting a possible role for sperm snRNAs in the intergenerational programming of metabolic diseases in humans.

[123] Suh N, Baehner L, Moltzahn F et al. MicroRNA function is globally suppressed in mouse oocytes and early embryos. Curr Biol 2010; 20:271-277.

[124] Roovers EF, Rosenkranz D, Mahdipour $M$ et al. Piwi proteins and piRNAs in mammalian oocytes and early embryos. Cell Rep 2015; 10:2069-2082.

[125] Hou YJ, Zhu CC, Duan X et al. Both diet and gene mutation induced obesity affect oocyte quality in mice. Sci Rep 2016; 6:18858.

[126] Luzzo KM, Wang Q, Purcell SH et al. High fat diet induced developmental defects in the mouse: oocyte meiotic aneuploidy and fetal growth retardation/brain defects. PLoS One 2012; 7:e49217.

[127] Huypens P, Sass S, Wu M et al. Epigenetic germline inheritance of diet-induced obesity and insulin resistance. Nat Genet 2016; 48:497-499.

* Using an in vitro fertilization approach, the authors showed that exposure of parental gametes to a high-fat diet modifies the epigenetic inoformation contained in egg and sperm, programming an insulin resistant phenotype mainly through the maternal line.

Figure 1. Influences of suboptimal pre-natal and post-natal environment on offspring cardiovascular health
Pre-gestational
Gestational (in utero)
Post-natal/adulthood
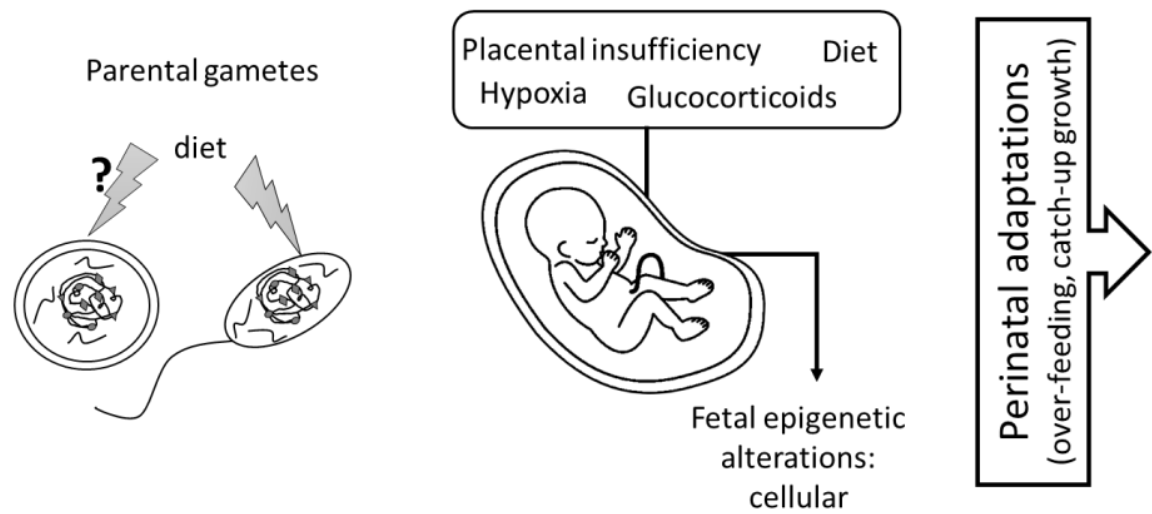

Vasculature

Endothelial dysfunction

Heart

Cardiac hypertrophy

Cardiac fibrosis

$\downarrow$ cardiomyocyte number

\section{Kidneys}

Impaired nephrogenesis

Impaired glomerulogenesis

Renal dysfunction

functional

metabolic 